\title{
ALAT SOLAR TRACKER BERBASIS MIKROKONTROLER 8 BIT ATMega8535
}

\author{
Oleh \\ I Wayan Sutaya \\ Jurusan Pendidikan Teknik Elektro Fakultas Teknik dan Kejuruan \\ Universitas Pendidikan Ganesha Singaraja \\ e-mail : sutaya.elkt@gmail.com
}

\begin{abstract}
ABSTRAK
Penelitian yang telah dilakukan ini adalah membuat prototipe alat solar tracker. Alat ini berfungsi untuk menggerakkan modul sel surya sehingga permukaan sel surya bisa terkena sinar matahari secara maksimal. Saat ini sel surya di Indonesia banyak terpasang secara statis atau tidak dilengkapi alat solar tracker sehingga energi matahari tidak diterima secara maksimal. Hal ini menyebabkan sel surya yang terpasang di beberapa daerah di Indonesia tidak memberikan manfaat yang optimal. Alat solar tracker yang dihasilkan pada penelitian ini diharapkan sebagai solusi dari permasalahan yang ada saat ini. Mikrokontroler 8 bit ATMega8535 yang digunakan sebagai otak utama dari alat solar tracker menjadikan alat ini menjadi berbiaya murah. Serta teknik memprogram dengan bahasa assembly menjadikan alat ini tahan terhadap kegagalan sistem. Solar tracker ini sudah bisa beroperasi dengan baik dan cocok digunakan pada modul sel surya berukuran kecil.
\end{abstract}

Kata-kata kunci: solar tracker, sel surya, mikrokontroler, bahasa assembly

\begin{abstract}
The research that was done is to making a solar tracker prototype. A solar tracker has a function to driving a solar cell module so the surface of a solar cell receives the light of sun maximally. The solar cell installed in some places in Indonesia is without a solar tracker so sun energy is not collected maximally. This causes the solar cell did not give an optimally benefit over the cost. The solar tracker that was made in this research is to be expected as a solution of the problem of uses solar cell in Indonesia. The 8 bit microcontroller ATMega8535 used as a main brain made the tracker costs cheaply. The choice of assembly language to code the algorithm made the tracker is not easy to get a fault in system. This Solar tracker works well and is suitable for small scale solar cell panel uses.
\end{abstract}

Key words: solar tracker, solar cell, microcontroller, assembly language

\section{PENDAHULUAN}

Di Indonesia sudah banyak terpasang modul sel surya yang berskala kecil dan kebutuhan modul sel surya ini terus meningkat. Hal ini disebabkan masih banyak jalanjalan di Indonesia yang belum ada penerangan dan sel surya menjadi sumber energi alternatif karena sebagai sumber energi yang murah. Saat ini modul sel surya yang terpasang di Indonesia hampir seluruhnya masih bersifat statis artinya modul sel surya ini tidak bisa bergerak untuk menghadap matahari terus menerus. Sehingga cahaya matahari yang diterima oleh modul sel surya ini tidak maksimum. Akibatnya energi yang dihasilkan oleh modul sel surya tidak maksimal.

Modul sel surya statis yang terpasang di daerah yang mempunyai ketinggian setara permukaan air laut mampu menerima sinar matahari $70 \%$ dalam sehari dan 
kemampuan ini terus berkurang seiring peningkatan ketinggian dari lokasi pemasangan (Bose, 2012). Sehingga pada beberapa kasus sering ditemukan lampu penerangan jalan yang menggunakan satu modul sel surya tidak bekerja secara maksimal alias tidak mampu hidup penuh satu malam karena kurangnya energi listrik yang dihasilkan oleh modul sel surya.

Pemasangan modul sel surya yang tidak dilengkapi solar tracker di Indonesia saat ini sangat tidak efektif karena sebagian besar wilayah di Indonesia adalah perbukitan. Untuk memaksimalkan energi yang dihasilkan oleh modul sel surya di Indonesia maka modul sel surya yang terpasang tersebut harus dilengkapi dengan solar tracker. Solar tracker berfungsi untuk menggerakkan modul sel surya agar bisa bergerak sehingga bisa menghadap matahari secara terus menerus. Dengan penambahan alat solar tracker, modul sel surya bisa menerima matahari secara maksimal sehingga energi yang dihasilkan juga maksimal.

Sistem Solar Tracker ada beberapa jenis dan bisa diklasifikasikan berdasarkan beberapa kriteria (Tudorache \& Kreindler, 2010). Klasifikasi pertama bisa dibuat berdasarkan pada jumlah sumbu putaran. Pada klasifikasi ini, solar tracker dibedakan menjadi dua yaitu: satu sumbu putaran dan dua sumbu putaran. Karena solar tracker mempunyai bagian penggerak dan sistem kontrol yang memerlukan biaya tinggi, maka solar tracker yang satu sumbu menjadi solusi terbaik untuk modul sel surya yang berukuran kecil.

Sistem Solar Tracker satu sumbu mempunyai tiga tipe (Dhanabar. R \& Bharathi. V. 2013) yaitu: Sistem Solar Tracker satu sumbu horizontal, Sistem Solar Tracker satu sumbu vertikal dan sistem Solar Tracker satu sumbu miring. Pada sistem Solar Tracker dua sumbu, dua rangkaian yang men-tracking cahaya terdiri dari empat sensor LDR yang sama yang diletakkan pada bagian timur, barat, selatan dan utara serta dua motor listrik yang diletakkan pada setiap sumbu (Salem, 2013).

\section{METODE}

\section{A. Blok Sistem Alat Solar Tracker}

Solar tracker yang dibuat pada penelitian ini adalah tipe satu sumbu. Alasan pemilihan satu sumbu karena solar tracker ini diperuntukkan modul sel surya yang berukuran kecil. Blok sistem alat solar tracker yang dibuat pada penelitian ini ditunjukkan pada Gambar 1 di bawah. 


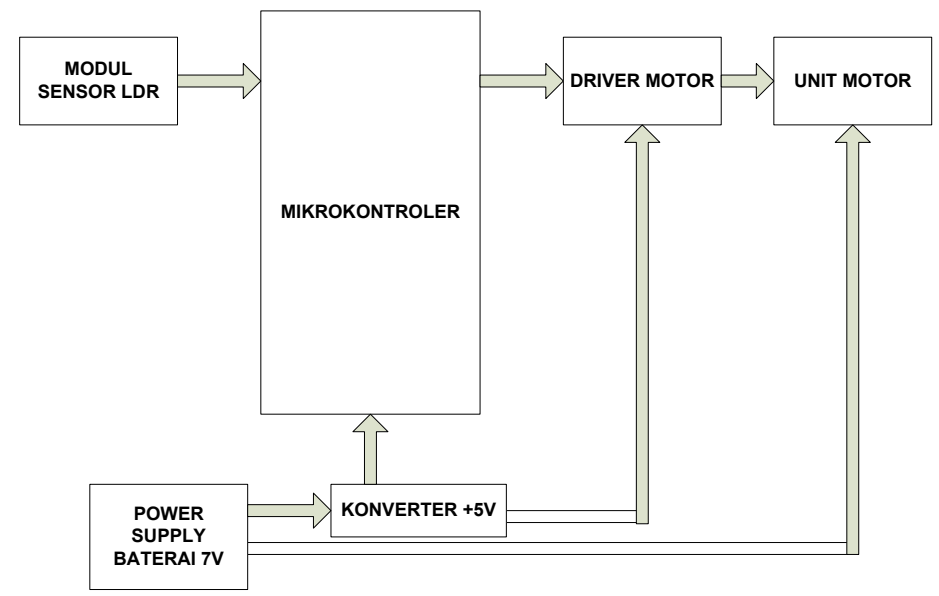

Gambar 1. Blok sistem alat solar tracker

Power supply yang digunakan di sini berupa dua buah baterai yang masingmasing 3.5 V sebanyak dua buah yang terpasang secara seri. Sehingga total tegangan dari power supply menjadi sebesar $7 \mathrm{~V}$. Alasan mengunakan baterai adalah sebagai media pengujian berapa daya yang habis dari kedua sistem model program yang akan digunakan. Mikrokontroler adalah bagian pengontrol utama dari keseluruhan sistem. Pada mikrokontroler ini akan tertanam program dari algoritma sistem tracking. Konverter berfungsi untuk merubah tegangan menjadi $5 \mathrm{~V}$ yang diperlukan oleh mikrokontroler dan unit driver. Sensor LDR ini sebagai input bagi mikrokontroler. Sensor menghasilkan tegangan dalam bentuk analog. Sehingga mikrokontroler akan mengkonversikannya menjadi digital untuk pengolahan lebih lanjut. Driver motor digunakan untuk menggerakkan motor. Driver motor ini akan mendapatkan tegangan rendah dari mikrokontroler yang selanjutnya menggerakkan motor sesuai dengan perintah dari mikrokontroler. Motor sebagai penggerak modul sel surya yang terpasang padanya. Motor ini akan menggerakkan modul sel surya ke kanan atau ke kiri sesuai dengan arah datangnya sinar matahari.

\section{B. Struktur dan Diskripsi Komponen}

Struktur dari alat solar tracker yang dibuat pada penelitian ini ditunjukkan pada Gambar 2 di bawah. Alat solar tracker ini menggerakkan sel surya dalam satu sumbu sehingga hanya memerlukan satu motor penggerak. Sensor LDR yang berjumlah dua buah diletakkan pada bagian penyangga modul sel surya yang ikut bergerak. 

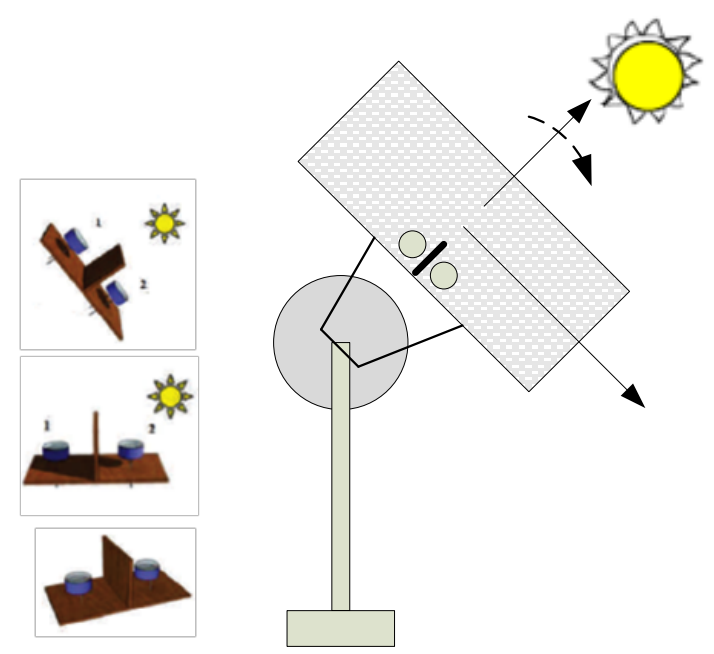

Gambar 2 Struktur alat solar tracker

Diskripsi komponen yang digunakan pada alat solar tracker ini dijelasakan seperti di bawah.

\section{Power supply}

Power supply yang menggunakan dua baterai diletakkan pada bagian yang statis atau tidak ikut bergerak pada alat solar tracker ini.

2. Mikrokontroler

Mikrokontroler yang digunakan di sini adalah ATMega8535 yang merupakan keluarga mikrokontroler ATMEL AVR. ATMega8535 adalah mikrokontroler 8-bit CMOS daya rendah 40 pin. Mikrokontroler ini menggunakan arsitektur RISC. ATMega8535 mempunyai tiga fitur utama yaitu: EEPROM 512 Byte, 32 programable I/O, konverter Analog to Digital 8 chanel 10 bit. Blok diagram dari ATMega8535 ditunjukkan pada Gambar di bawah berikut (Kumar \& Sarma. 2013). 


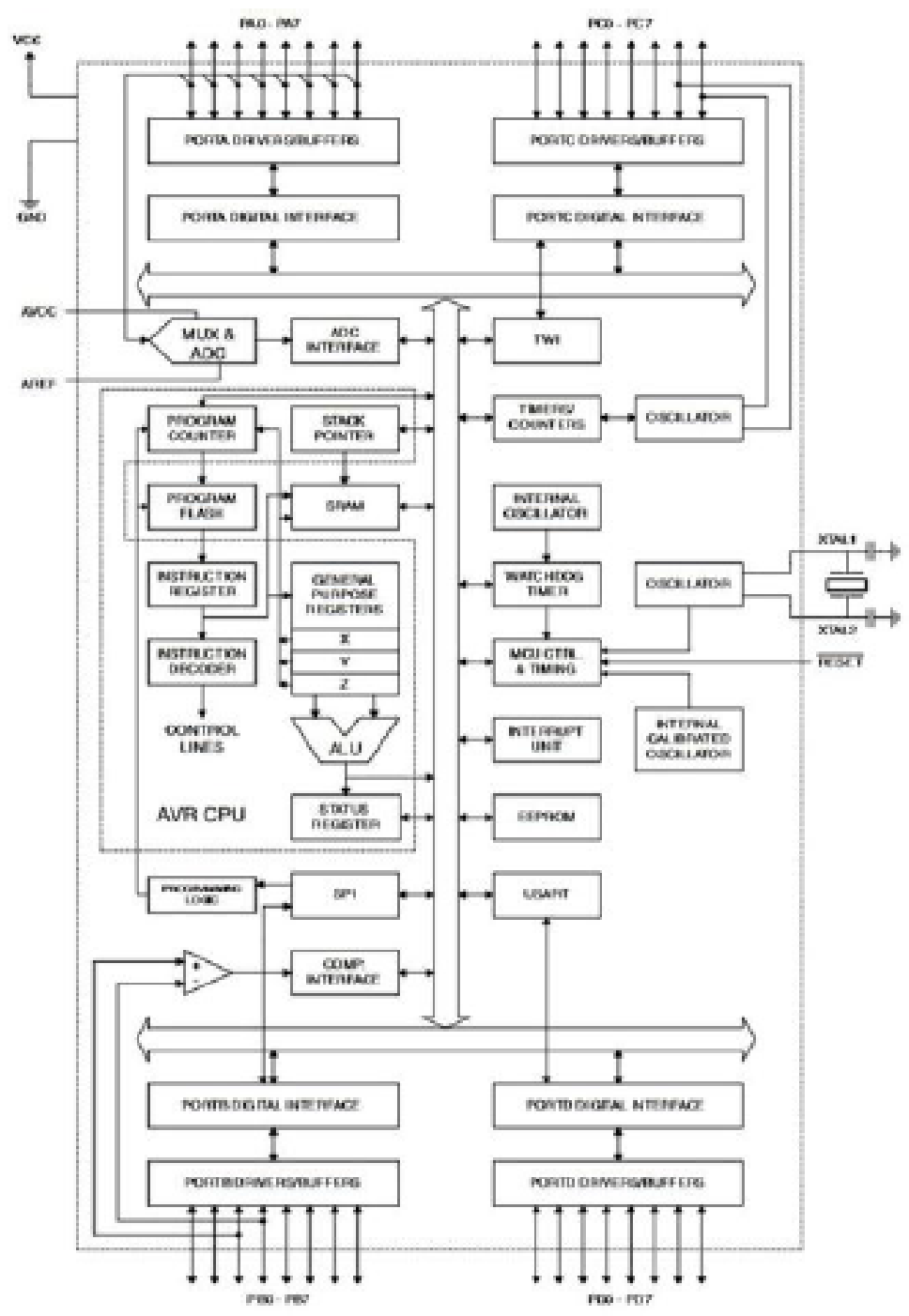

Gambar 3. Arsitektur mikrokontroler ATMega8535

\section{Sensor LDR}

Sensor LDR adalah sensor cahaya yang digunakan untuk merasakan intensitas sinar matahari. Sensor LDR yang digunakan di sini menggunakan Cadmium Sulphide (CDS) photocell untuk merasakan cahaya. Photocell adalah komponen pasif yang resistansinya berbanding terbalik dengan besar intensitas cahaya. Sensor ini terhubung secara seri dengan resistor. 


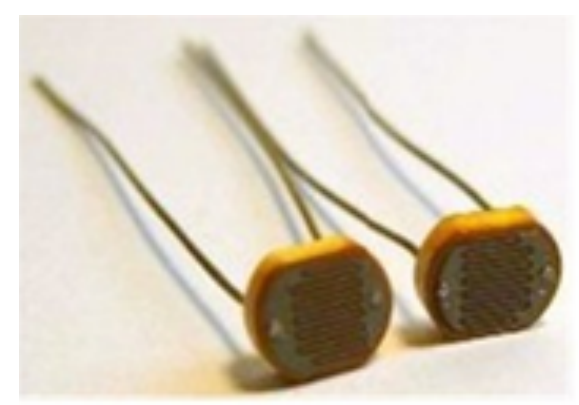

Gambar 4. Sensor LDR

4. Driver motor DC

Driver motor adalah rangkaian yang menggunakan transistor daya dalam mensupply arus untuk motor DC.

5. Motor

Motor yang digunakan pada penelitian ini adalah motor DC 6V. Motor ini dilengkapi gear box $1: 70$.

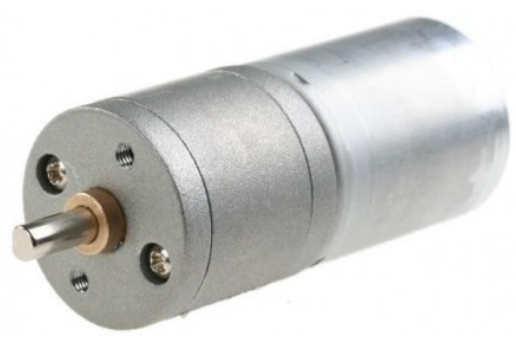

Gambar 5. Motor DC 6V yang dilengkapi dengan gear box

\section{Desain Hardware}

Desain hardware secara keseluruhan dari alat solar tracker ditunjukkan pada Gambar 6 di bawah. Mikrokontroler digunakan sebagai otak utama dari alat solar tracker yang dibuat. Masukan dari perangkat solar tracker berupa sinyal analog dari sensor cahaya yang terhubung pada port A pin 1 dan port A pin 2. Di sini pin yang digunakan sebanyak dua buah karena sensor yang terhubung juga sebanyak 2 buah. Besar tegangan analog dari sensor yang masuk ini akan dikonversikan menjadi besaran digital dimana mikrokontroler ATMega8535 mempunyai 8 buah pin yang bisa mengkonversikan sinyal analog menjadi sinyal digital. Sedangkan keluaran dari mikrokontroler keluar pada port C pin 0 dan pin 3. Di sini menggunakan dua pin keluaran agar motor bisa dikendalikan untuk bergerak ke kiri dan ke kanan. 


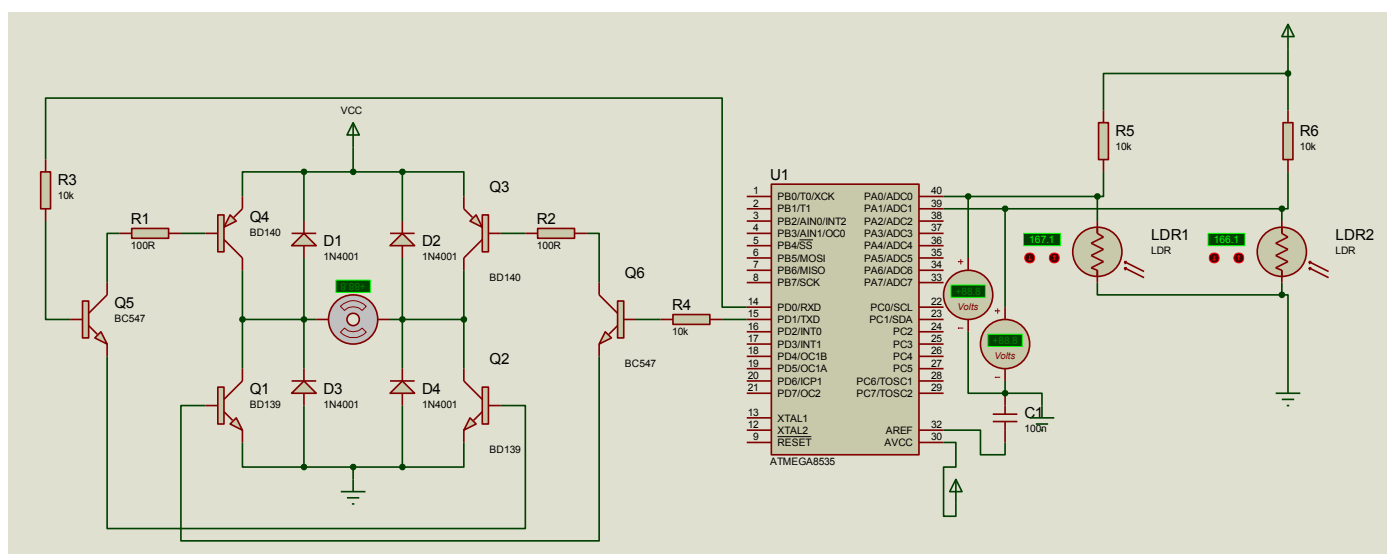

Gambar 6. Desain rangkaian alat solar tracker

Proses desain rangkaian alat solar tracker yang telah dilakukan menggunakan software proteus. Desain rangkaian dari alat solar tracker di kategorikan menjadi tiga blok dimana penjelasan perblok dari desain hardware ini dijelasakan seperti berikut.

1. Rangkaian minimum sistem

Rangkaian minimum sistem adalah rangkaian minimum yang diperlukan agar sebuah mikrokontroler (otak dari alat solar tracker) bisa bekerja. Poin utama dalam membuat rangkaian minimum ini adalah ukuran kristal yang digunakan. Ukuran Kristal ini akan menentukan besar clock dari sebuah mikrokontroler. Clock ini berpengaruh pada kecepatan proses dari sebuah mikrokontroler. Pada penelitian ini Kristal yang digunakan berukuran 11.5 MHz. Dari sini dapat diketahui besar clock dari mikrokontroler ini adalah 1/11.5 MHz atau sama dengan 860 us.

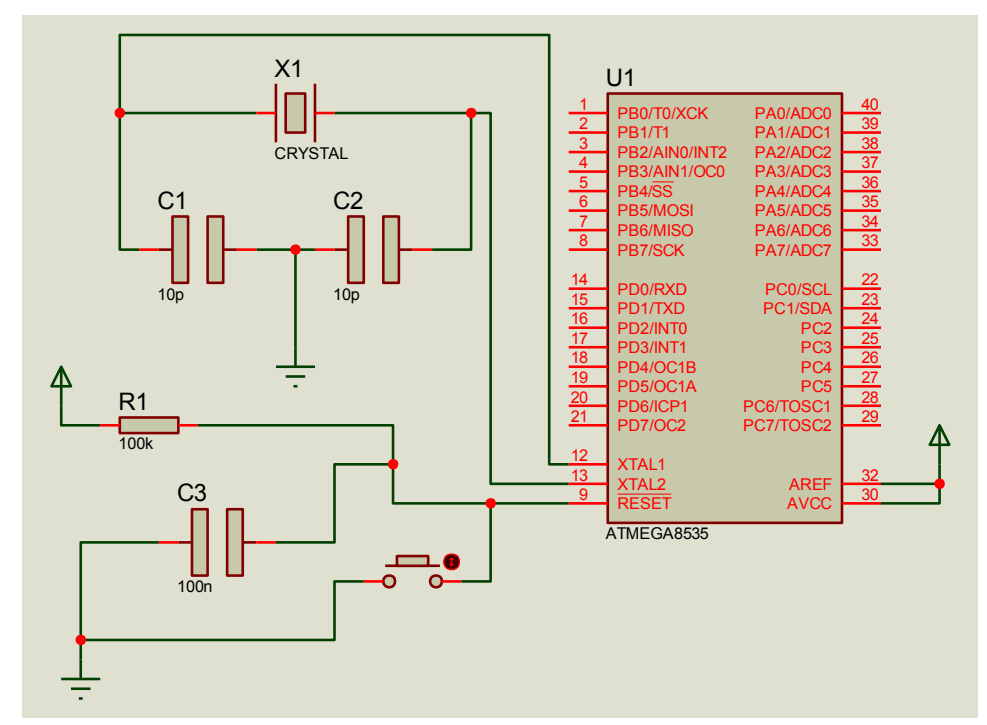

Gambar 7. Desain rangkaian minimum sistem 
2. Rangkaian driver kendali motor

Rangkaian driver yang didesain di sini berguna untuk mengendalikan motor DC. Rangkaian driver mendapatkan perintah atau masukan dari mikrokontroler. Apabila pin 0 dari port $\mathrm{C}$ yang mengeluarkan tegangan maka motor $\mathrm{DC}$ akan bergerak ke kanan. Sedangkan apabila pin 1 dari port $\mathrm{C}$ yang mengeluarkan tegangan maka motor akan bergerak ke kiri. Pada rangkaian ini menggunakan 2 transistor sinyal rendah dan 4 transistor power.

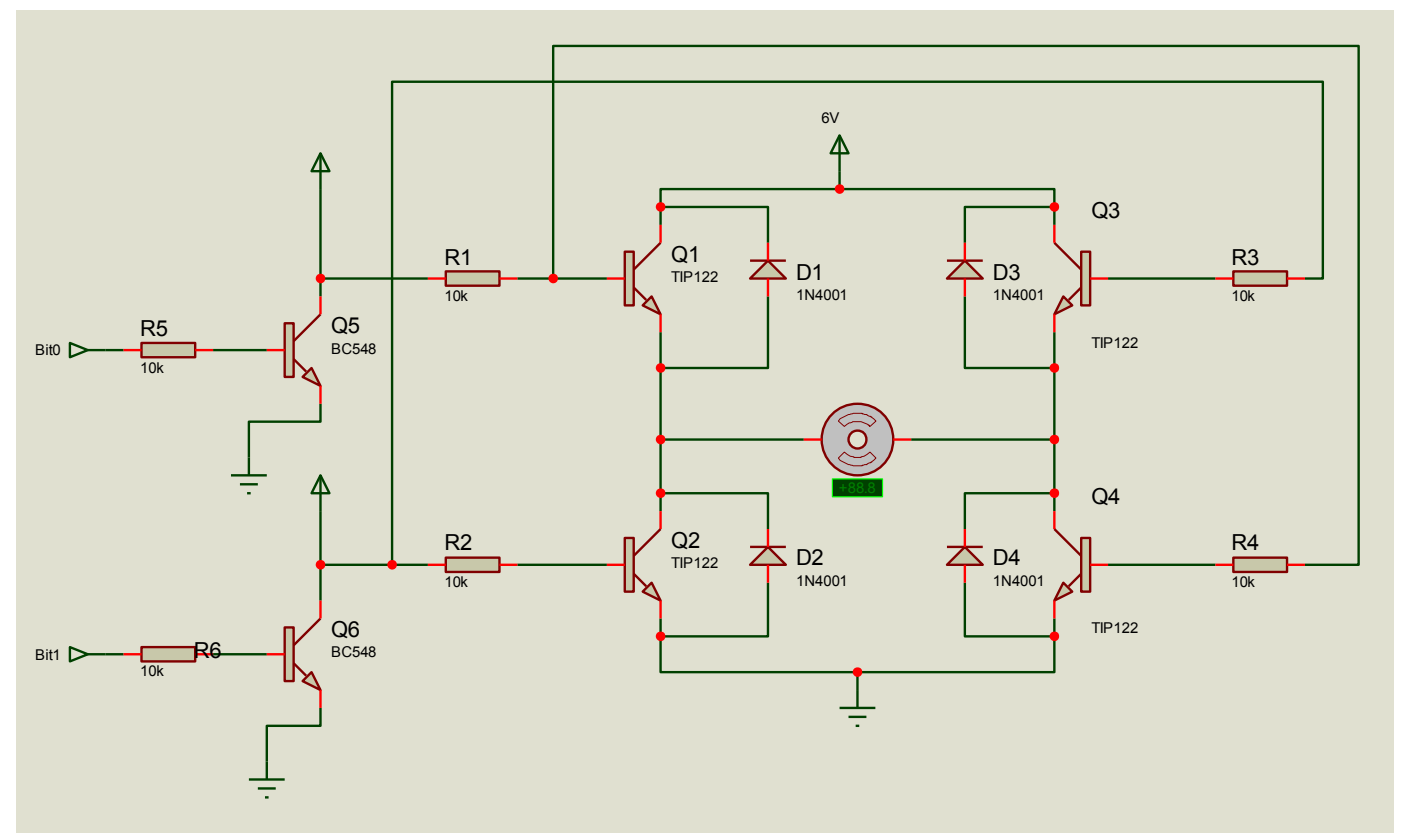

Gambar 8. Rangkaian driver kendali motor DC

3. Desain rangkaian sensor

Desain rangkaian sensor yang telah dibuat disini berguna sebagai inputan bagi mikrokontroler sehingga mikrokontroler tahu posisi arah datangnya sinar matahari. Di sini terdapat dua rangkaian sensor cahaya. Prinsip kerja dari rangkaian sensor ini adalah seperti rangkaian pembagi tegangan. Sehingga sensor LDR dipasang secara seri dengan resistor. Output dari rangkaian sensor ini diambil pada titik tengah antara resistor dan sensor cahaya. Semakin besar intensitas cahaya yang datang maka nilai tahanan pada sensor akan semakin mengecil sehingga tegangan out menjadi membesar. Begitu pula sebaliknya apabila intensitas cahaya yang datang sedikit maka tahanan sensor akan membesar sehingga menyebabkan tegangan out menjadi mengecil. 


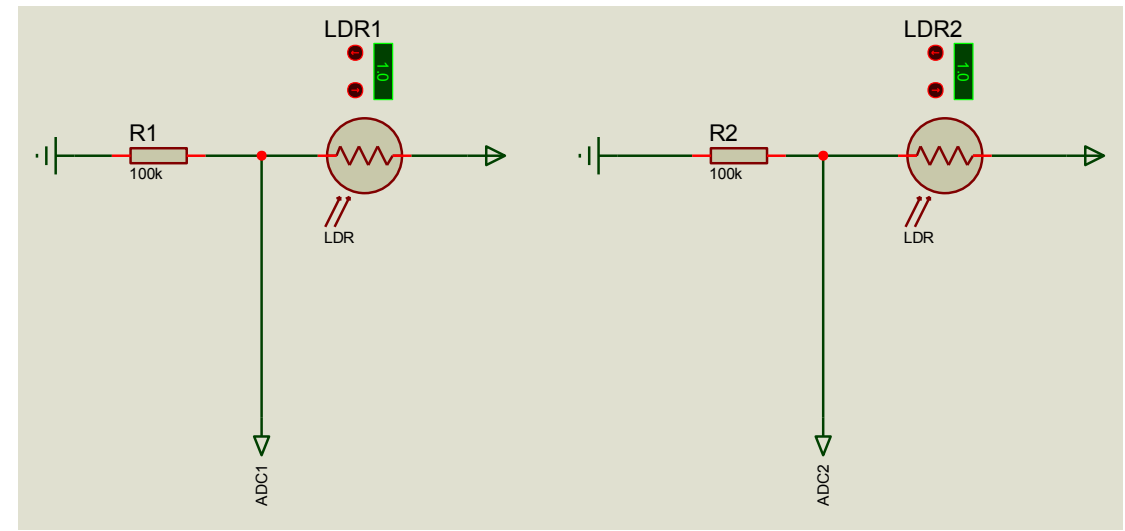

Gambar 9. Desain rangkaian sensor

\section{Desain Program/Software}

Algoritma dari alat solar tracker yang telah dibuat pada penelitian ini ditunjukkan pada Gambar 10 di bawah. Dari gambar tersebut dapat dijelaskan bahwa data yang diberikan oleh dua sensor disimpan pada dua variabel yang berbeda. Selanjutnya data yang disimpan pada variabel-variabel ini ditambahkan dengan 15 kemudian disimpan pada variabel Buffsensor1 dan Buffsensor2. Kegunaan dari variabel-variabel ini adalah untuk memberikan rentang perbedaan sehingga motor tidak diperintahkan terus menerus bergerak pada setiap ada perbedaan nilai tegangan antara dua sensor. Tetapi ditentukan rentang minimal perbedaan yang menyebabkan motor harus bergerak. Selanjutnya terjadi pengecekan apakah tegangan pada sensor1 lebih kecil dari tegangan pada sensor 2. Apabila lebih kecil maka motor DC akan diperintahkan untuk bergerak ke kiri. Motor akan diperintahkan untuk bergerak ke kanan apabila terjadi hal yang sebaliknya. Selanjutnya akan ada proses tunda sebesar 1 detik untuk melakukan proses selanjutnya yaitu mengambil data dari sensor. Hal ini diperlukan karena solar tracker tidak memerlukan pergerakan yang cepat dalam mentrack sinar matahari sehingga bisa mengurangi beban kerja dari perangkat alat solar tracker dengan melakukan proses idling. 


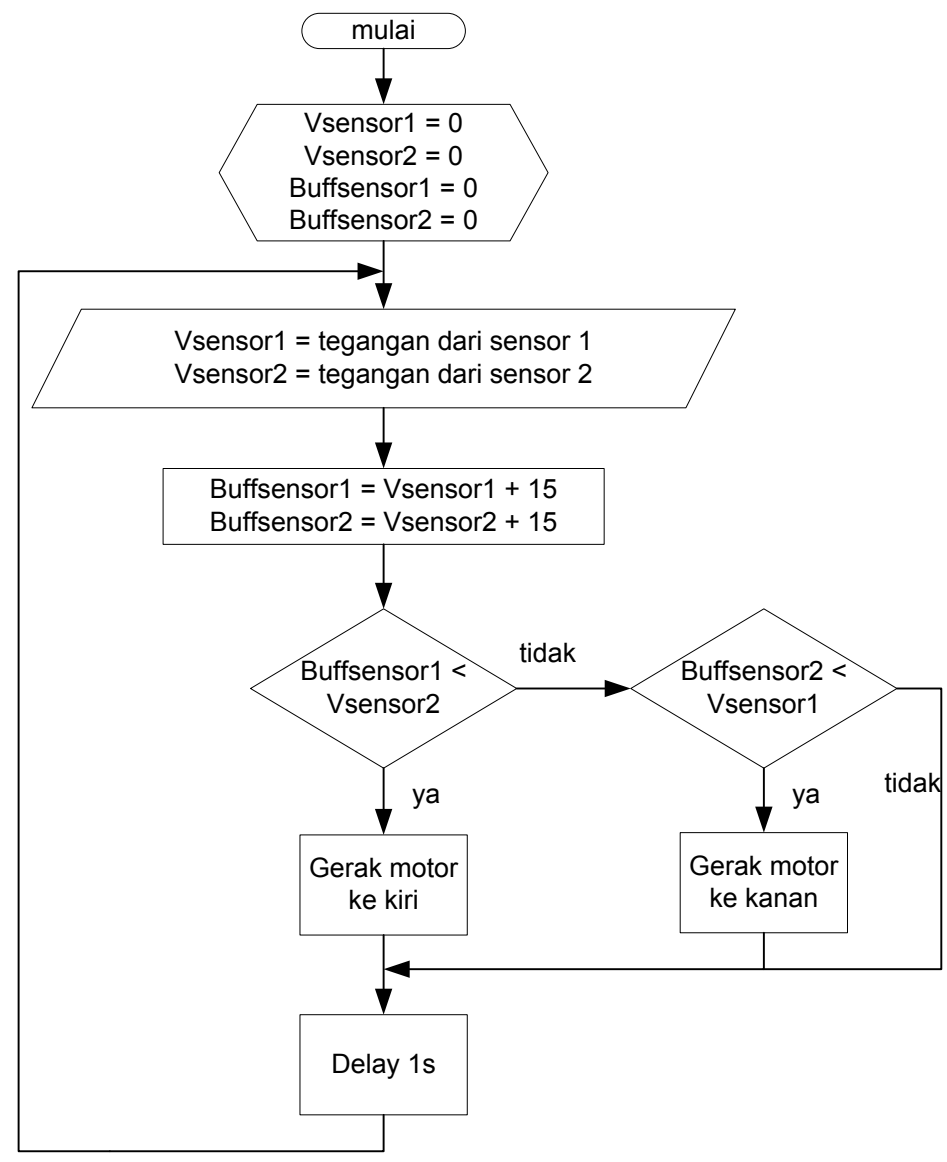

Gambar 10. Algoritma alat solar tracker

Algoritma diimplementasikan dengan menggunakan bahasa assembly. Penggunaan assembly disini karena bisa mengurangi besar ukuran program serta membuat sistem menjadi lebih tangguh terbebas dari kegagalan. Selain itu bahasa assembly menggunakan fitur-fitur hardware secara langsung sehinga bisa menangani waktu kritis (Schmidt, 2011). Teks editor yang digunakan untuk membuat program ini adalah AVR Studio 4.2. Software ini bersifat free atau tidak berbayar karena dibuat oleh perusahan ATMEL yang memproduksi chip mikrokontroler keluarga AVR.

\section{HASIL DAN PEMBAHASAN}

Alat prototipe solar tracker yang dihasilkan pada penelitian ini ditunjukkan pada Gambar 11 di bawah. Pengujian secara keseluruhan menunjukkan bahwa alat ini mampu mencari arah datanganya sinar. Ketika rangkaian pada sensor1 mengeluarkan tegangan output sebesar $4.65 \mathrm{~V}$ dan rangkaian pada sensor2 mengeluarkan tegangan sebesar 4.06 tidak ada pergerakan pada motor. Hal ini menandakan bahwa motor tidak selalu bergerak setiap ada perbedaan tegangan pada kedua sensor melain harus mencapai perbedaan lebih 
kecil dari $59 \mathrm{mV}$. Dari pengamatan secara langsung saat papan sel surya tidak bergerak, posisi papan sudah tegak lurus dengan arah datanganya sinar.

Tabel 1. Pengamatan pergerakan papan sel surya pada alat solar tracker

\begin{tabular}{|c|c|c|c|c|}
\hline No. & Vsensor1 (Volt) & Vsensor2 (Volt) & Perbedaan & Bergerak \\
\hline 1 & 4.50 & 4.09 & $41 \mathrm{mV}$ & Ya \\
\hline 2 & 4.55 & 4.08 & $47 \mathrm{mV}$ & Ya \\
\hline 3 & 4.60 & 4.07 & $53 \mathrm{mV}$ & Ya \\
\hline 4 & 4.65 & 4.06 & $59 \mathrm{mV}$ & Tidak \\
\hline 5 & 4.66 & 4.05 & $61 \mathrm{mV}$ & Tidak \\
\hline
\end{tabular}

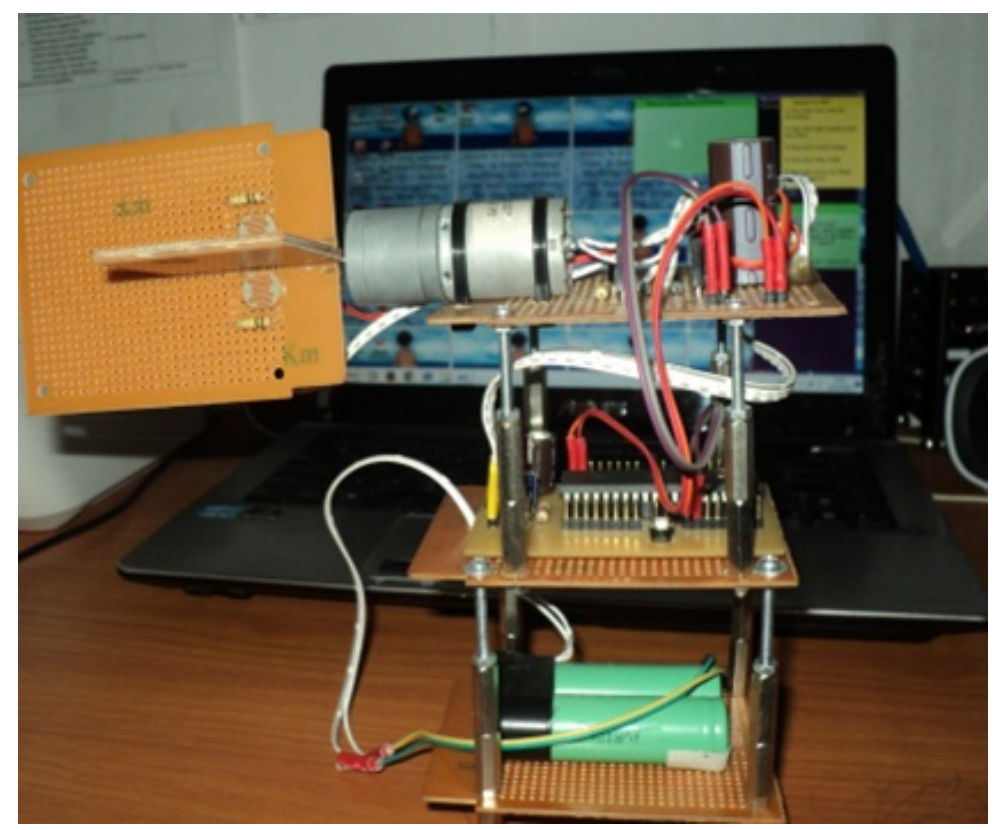

Gambar 11 Prototipe alat solar tracker

Pengujian rangkaian driver untuk motor DC dan rangkaian minimum sistem ditunjukkan pada Gambar 12 di bawah. Dimana semua rangkaian ini sudah beroperasi pada tegangan sesuai dengan perancangan yang telah dilakukan. 


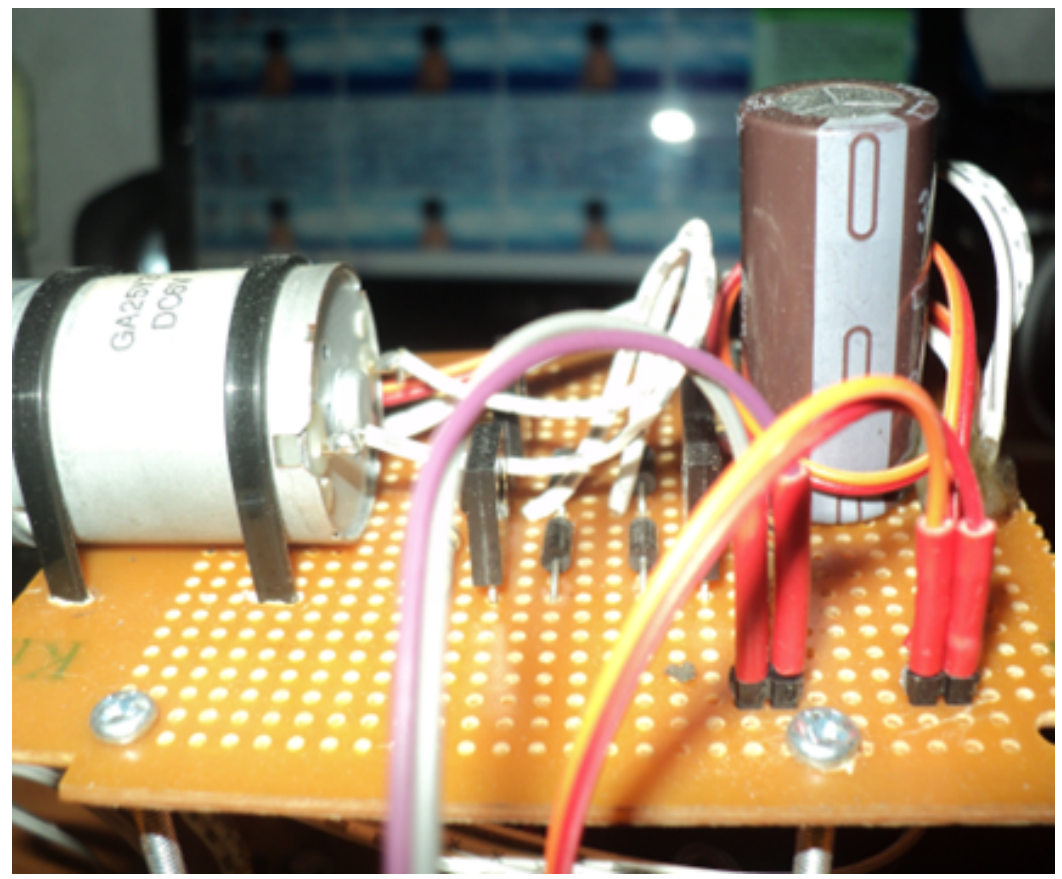

Gambar 12. Blok rangkaian driver

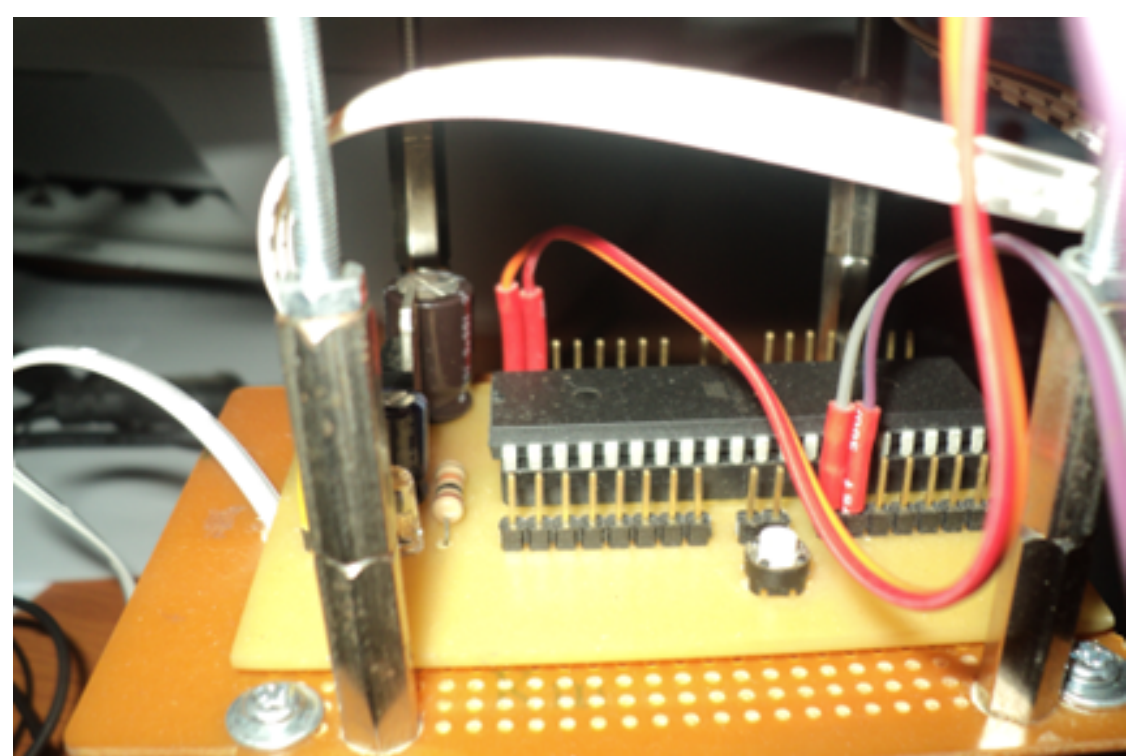

Gambar 13. Blok rangkaian minimum sistem 


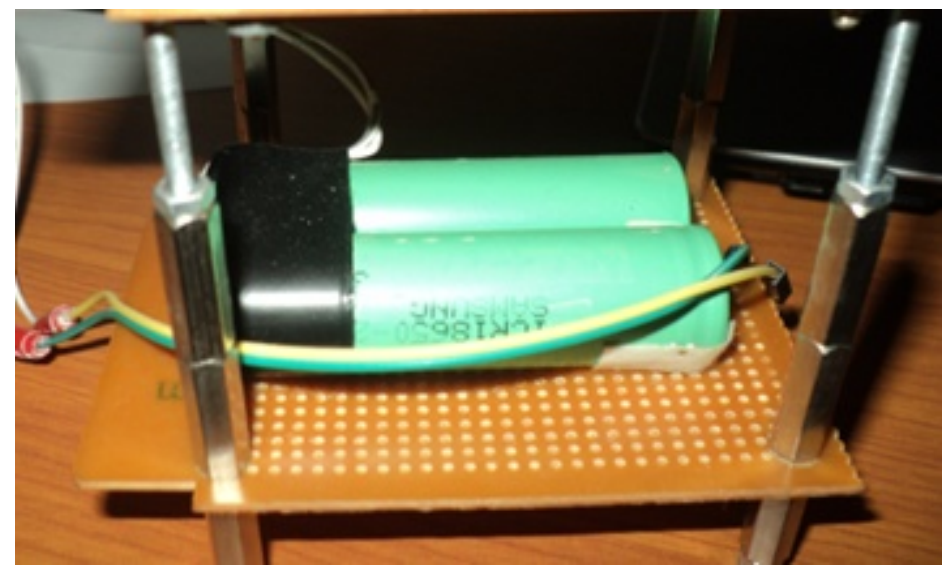

Gambar 14. Blok rangkaian baterai

Dari hasil pengujian alat solar tracker yang dibuat pada penelitian ini sudah bisa bekerja dengan baik. Dalam men-tracking arah datangnya sinar, alat ini tidak terlalu banyak menggerakkan motor karena disini digunakan rentang dari perbedaan sensor masukan. Walupun demikian posisi panel sel surya yang digerakkan oleh alat ini tetap berada pada posisi tegak lurus dengan arah datangnya sinar. Kekurangan dari alat ini adalah jika terjadinya noise atau ganguan pada masukan sensor seperti adanya benda yang menghalangi permukaan sensor maka motor akan bergerak secara terus menerus. Untuk menangani permasalahan ini maka perlu ditambahkan algoritma filter. Algoritma filter ini akan memfilter noise yang masuk pada sensor. Untuk mengimplementasikan algoritma filter pada mikrokontroler 8 bit memerlukan tantangan tersendiri mengingat mikrokontroler ini mempunyai sumber daya yang sangat terbatas.

\section{SIMPULAN}

Kesimpulan yang bisa dibuat dari penelitian pembuatan alat solar tracker ini adalah sebagai berikut:

1. Pergerakkan dari alat solar tracker yang dihasilkan pada penelitian ini sangat efesien hal ini dikarenakan penggunaan rentang perbedaan tegangan antara dua sensor.

2. Papan solar sel yang digerakkan oleh alat solar tracker sudah bisa berada selalu tegak lurus dengan arah datangnya cahaya.

3. Beban kerja dari mikrokontroler sangat ringan karena program menggunakan bahasa assembly yang bermain pada level register sehingga mencegah terjadinya kegagalan/fault pada sistem. 


\section{DAFTAR PUSTAKA}

Bose, A., Sarkar, S., 2012, Helianthus - a Low Cost High Efficient Solar Tracking System Using AVR Microcontroller, International Journal of Scientific \& Engineering Research, Volume 3, Issue 10, October-2012, ISSN 2229-5518.

Dhanabar, R., Bharathi V., 2013, Comparison of Efficiencies of Solar Tracker systems with static panel Single-Axis Tracking System and Dual-Axis Tracking System with Fixed Mount, International Journal of Engineering and Technology (IJET), Vol. 5, No. 2, Apr-May 2013, ISSN : 0975-4024.

Kumar, P.U., Sarma, G.R.C.K., 2013, An Embedded System Design In Automation of Street Lights Using AtMega 8535 Microcontroller, International Journal of Science, Engineering and Technology Research (IJSETR), Volume 2, No. 6, June 2013, ISSN: $2278-7798$.

Salem, F.A., 2013. Mechatronics Design of Solar Tracking System, International Journal of Current Engineering and Technology, Vol.3, No.3, (August 2013), ISSN 2277 4106.

Schmidt, G., 2011, Beginners Introduction to the Assembly Language of ATMEL-AVRMicroprocessors. Buku online: http://www.avr-asm-tutorial.net. (Diakses tanggal: 1 April 2014).

Tudorache, T., Kreindler, L., 2010. Design of a Solar Tracker System for PV Power Plants, Acta Polytechnica Hungarica, Volume 7, Number 1. 